\title{
Farklı Çift Sıra, Dar Sıra ve Tek Sıra Ekim Sistemlerinde Değişik Bitki Yoğunluklarının Mısır Bitkisinin (Zea mays L. indentata) Verim ve Verim Öğelerine Etkisi
}

\author{
Abdullah ÖKTEM ${ }^{1, *}$, Nurettin KOŞAR ${ }^{1}$
}

\begin{abstract}
ÖZ
Araştırmada 5 farklı ekim sistemi ve 3 farklı bitki yoğunluğu denenmiştir. Ekim sistemleri dar sıra (35-35-35 cm), çift sıra $(35-70-35 \mathrm{~cm})$, çift sıra $(20-50-20 \mathrm{~cm})$, çift sıra $(30-40-30 \mathrm{~cm})$ ve tek sıra $(70-70-70 \mathrm{~cm})$ olarak, bitki yoğunlukları ise 8500 bitki da $^{-1}, 10500$ bitki da $^{-1}$ ve 12500 bitki da $^{-1}$ olarak oluşturulmuştur. Ana parsellerde ekim sistemleri, alt parsellerde ise bitki yoğunlukları yer almıştır. Ekim sistemleri bakımından en yüksek tane verimi $1261.55 \mathrm{~kg} \mathrm{da}^{-1}$ ile çift sıra (35-70-35) ekim sisteminde elde edilmiștir. Bitki yoğunluğu bakımından ise en yüksek tane verimi $1100.40 \mathrm{~kg}$ $\mathrm{da}^{-1}$ ile 10500 bitki da $^{-1}$ bitki sayısından elde edilmiştir. Dekarda bitki sayısının artması ile bitki boyu ve bitkide yaprak sayısı artarken, kaçan kalınlığı, koçan uzunluğu, koçanda tane sayısı, koçanda tane ağırlı̆̆ı ve bin tane ağırlığı azalmıştır. Çift sıra (35-70-35) x 10500 bitki da $^{-1}$ interaksiyonu (1425.66 $\mathrm{kg} \mathrm{da}^{-1}$ ) denenen ekim sistemleri arasında en iyi kombinasyon olarak belirlenmiştir.
\end{abstract}

Anahtar Kelimeler: Mısır, ekim sistemi, çift sıra, dar sıra, tek sıra, ekim sıklığı

\section{Effect of Twin Row, Narrow Row and Single Row Sowing Systems and Plant Densities to Yield and Yield Characteristics of Corn (Zea mays L. indentata)}

\begin{abstract}
Five different sowing systems and three plant densities were tested in the study. Sowing systems were narrow row $(35-35-35 \mathrm{~cm})$, twin row $(35-70-35 \mathrm{~cm})$, twin row $(20-5020 \mathrm{~cm})$, twin row $(30-$ $40-30 \mathrm{~cm}$ ) and single row $(70-70-70 \mathrm{~cm})$, whereas plant densities were 8500 plant da $^{-1}, 10500$ plant $\mathrm{da}^{-1}$ and 12500 plant $\mathrm{da}^{-1}$. Main plots were sowing systems and sub plots were plant densities. In sowing systems, the highest grain yield was found at twin row (35-70-35) sowing system (1261.55 $\left.\mathrm{kg} \mathrm{da}^{-1}\right)$. In plant densities, the highest grain yield was found at $10500 \mathrm{plant} \mathrm{da}^{-1}\left(1100.40 \mathrm{~kg} \mathrm{da}^{-1}\right)$ plant density. With the increase in the number of plants per decare, the plant height and the number of leaves in the plant increased, while the ear diameter, the length of the ear, the number of grains on the ear, the grain weight of ear and thousand-grain weight values decreased. Twin row (35-7035) $\mathrm{x} 10500$ plants $^{-1}$ interaction $\left(1425.66 \mathrm{~kg} \mathrm{da}^{-1}\right)$ was determined as the best combination among the tested sowing systems.
\end{abstract}

Keywords: Corn, sowing systems, twin row, narrow row, single row, plant density

ORCID ID (Yazar sirasına göre)

0000-0001-5247-7044, 0000-0002-5155-4075

\footnotetext{
Yayın Kuruluna Geliş Tarihi: 01.06.2021

Kabul Tarihi: 17.12.2021

${ }^{1}$ Harran Üniversitesi Ziraat Fakültesi Tarla Bitkileri Bölümü, Şanlıurfa

*E-posta: aoktem@harran.edu.tr
} 


\section{Farklı Çift Sıra, Dar Sıra ve Tek Sıra Ekim Sistemlerinde Değişik Bitki Yoğunluklarının Mısır Bitkisinin (Zea mays L. indentata) Verim ve Verim Öğelerine Etkisi}

\section{Giriş}

Dünyada ve ülkemizde yetiştirilen mısırların büyük çoğunluğunu at dişi misır çeşitleri oluşturmaktadır. Mısır bitkisi yeşil yem, kuru yem ve silaj yemi olarak hayvan beslenmesinde kullanılmaktadır. Ayrıca taneleri kesif yemlerin ana bileşeni durumundadır. Hammadde olarak endüstride çok geniş bir yelpazede kullanımının yanında doğrudan ve dolaylı olarak insan beslenmesinde de kullanılmaktadır. Ayrıca işlenmiş ve işlenmemiş gıda maddelerinde katkı maddesi olarak yer almaktadır. Mısır nişastası, misır şurubu, mısırözü yağı endüstride ve gida sanayiinde aranan hammaddelerdir. Misir tanesinden elde edilen nişasta bazlı şekerlerin kullanımı hem ucuz olması hem de pratik olması nedeniyle vazgeçilmez konuma yükselmiştir. Ayrica misir tanesi biyoetanol elde edilmesinde kullanılmakta ve biyoyakıt üretimine katk1 sağlamaktadır. Bütün bu sayılanlar nedeniyle mısır ürünü ekonomiye katkı sağlayan vazgeçilmez ve önemli bir bitkidir.

Mısır bitkisi entansif tarım şartlarında yetiştirilmeye son derece uygun, güneş enerjisinden kısa sürede ve en yüksek seviyede yararlanarak birim alandan yüksek miktarda dane ürünü ve kuru madde üreten bir bitkidir. Günümüzde yüksek verimli hibrit mısır çeşitleri verimi belli bir noktaya taşımıştır. Ancak bu potansiyelin uygun yetiştirme teknikleri kullanılarak birim alandan daha fazla üretim sağlayacak en uygun yetiștirme tekniklerinin pratiğe aktarılması gerekmektedir. Bu bağlamda mısır tarımında verim artışı sağlayacak yeni ekim sistemlerinin test edilerek pratiğe aktarılması gerekmektedir.

Mısır ekimi yapılan alanlarda güneşli gün sayısı ve güneşlenme süresi yüksektir. Dik yapraklı mısır çeşitleri güneş 1şı̆̆ından daha uzun süre yararlandığ 1 için daha fazla fotosentez yaparak birim alanda daha fazla asimilant üretmektedir. Dik yapraklı gelişen mısır çeşitleri aynı zamanda sık ekime de daha iyi tolerans göstermektedir. Ülkemizin güneşlenme süresi potansiyelinden yararlanarak ve dik yapraklı hibrit mısır çeşidi kullanarak çift sıra ve dar sıra ekim sistemlerinin geleneksel ekim sistemine göre karşılaştırması oldukça önemlidir.
Birim alandaki bitki sayısını arttıran bu uygulamalardan olumlu sonuç alındığında, mevcut alet, ekipman ve mekanizasyon varlığının yeni sisteme kolaylıkla uyarlanması, özellikle çift sıra yönteminde herhangi bir problem ile karşılaşı1mayacağı, demonstrasyon çalışmaları ile çiftçilere bu sistemin tanıtılabileceği ve çiftçilerin bu tekniği benimseyerek yararlanabileceği düşünülmektedir. Söz konusu ekim yöntemlerinin ülkemiz misır üretim potansiyelinin artmas1, bölge ve ulusal ekonomiye, toplumsal refaha katk1 sağlayabilecektir.

Misirda sira aralarının daraltılması (narrow row) ve bir sıra yerine iki sıra şeklinde mısır ekimi (twin row) ile ilgili çalışmalara dünyada rastlamamıza rağmen ülkemizde bu konu ile ilgili az sayıda çalışma bulunmaktadır. Çift sıra (twin row) ve dar sira (narrow row) ile ilgili çalışmalar, ABD' de 1980'li yıllarda başlamış, günümüzde de devam etmektedir. Güney Amerika'da yürütülen bir araştırmada, mısırda çift sıra uygulamasında tek sıra uygulamasına göre daha yüksek tane verimi alındığını ve en yüksek verimin çift sıra uygulamasında yüksek bitki popülasyonundan (98 000 bitki ha $^{-1}$ ) elde edildiği bildirilmiştir (Karlen ve Camp, 1985). Uzun yıllar Güney Amerika'da 7 farklı lokasyonda yürütülen bir çalışmada, mısırda dar sıra aralığ 1 ve çift sıra ekim yönteminin tek sıra ekim yöntemine göre önemli tane verimi artışına neden olduğu bildirilmiştir. Ayrıca çift sıra mısır ekiminde geleneksel sistemde kullanilan alet ve ekipmanların kullanılabilmesi, çift sıranın dar sıraya göre çok daha pratik bir alternatif olabileceği belirtilmiştir (Karlen ve ark., 1987). Çift sıra ve tek sıra uygulamalarında tek sıra uygulamasina göre daha yüksek tane verimi elde edildiği, en yüksek tane veriminin 9000 bitki da $^{-}$ ${ }^{1}$ uygulamasından, 12000 bitki da ${ }^{-1}$ ve 13000 bitki $\mathrm{da}^{-1}$ uygulamalarında ise daha düşük verimler elde edildiği bildirilmiştir (Gözübenli ve ark., 2004).

Cox ve ark. (2006) Amerika Birleșik Devletleri'nin kuzeybatısında misır bitkisinde dar sira aralığında $(0.38 \mathrm{~m})$, geleneksel sira aralığına göre $(0.76 \mathrm{~m})$ daha yüksek verim almışlardır. Kuru madde verimleri dar sırada 


\section{Farklı Çift Sıra, Dar Sıra ve Tek Sıra Ekim Sistemlerinde Değişik Bitki Yoğunluklarının Mısır Bitkisinin (Zea mays L. indentata) Verim ve Verim Öğelerine Etkisi}

$17.6 \mathrm{t} \mathrm{ha}^{-1}$, çift sırada $17.2 \mathrm{t} \mathrm{ha}^{-1}$, geleneksel sırada $16.6 \mathrm{t} \mathrm{ha}^{-1}$ olmuştur. Araştırıcılar çift sıra aralığı uygulamasının geleneksel geniş sıra aralığı ekim yönteminde kullanılan alet ekipmanların modifiye edilerek kullanılma olanağı olmasından dolayı, dar sıra aralığına göre daha avantajlı olduğunu bildirmişlerdir. Çift sıra ve dar sıra ekim sisteminin geleneksel ekim sistemi ile karşılaştırıldı̆̆ bir araştırmada, çift sıra uygulamasının verimde geleneksel ekim yöntemine göre $\% 16$, dar sira ekime göre $\% 7.9$, kuru madde veriminde ise geleneksel ekim yöntemine göre $\% 10.2$, dar sira ekim yöntemine göre \% 5.9 daha avantajlı bulunduğu bildirilmiștir (Yılmaz ve ark., 2008).

Misırda tek sıra, basit çift sıra ve zigzag çift sıra konuları ile bu konularda metrekarede 7, 10, 13 adet bitki ${ }^{-1}$ sayısının araştırıldığı çalışmada, en yüksek tane verimi çift sıra uygulamalarından ve 10 adet $\mathrm{m}^{-2}$ uygulamasından, en düşük tane veriminin tek sira uygulamasinın 13 adet $\mathrm{m}^{-2}$ konusunda görüldüğü belirtilmiştir (Shakarami ve Rafiee, 2009).

Hatay koşullarında yapılan bir araştırmada, çift sıra ve dar sıra mısırda, geleneksel geniş sıra aralığına göre daha iyi verim elde edildiği bildirilmiştir (Gözübenli, 2010). Çift sıra yöntemiyle yapılan bir başka çalışmada tane verimi, koçanda tane sayısı ve hasat indeksinin arttığı, koçan boyu ve koçan çapı özelliklerinin ise azaldığı belirtilmiştir (Eskandarnejad ve ark., 2013). Çift sıra misır yetiștiriciliğinin avantajlarından birisi olarak çift sıra ekiminde yabancı ot sorunu için ilaç uygulamasına gerek duyulmadığ 1 bildirilmiştir (McGrath ve ark., 2013).
$\mathrm{Bu}$ çalışmada, farklı bir yetiştirme tekniği olan çift sıra (twin row), dar sıra (narrow row) ve tek sira (single row) ekim sistemlerinin misir bitkisinin verim ve verim unsurlarına etkisi belirlemek, bu ekim sistemlerini birbirleriyle karşılaştırmak ve literatüre katk1 sağlamak amaçlanmıştır.

\section{Materyal ve Yöntem}

Denemede dik yapraklı DKC-5783 atdişi hibrit mısır çeşidi kullanılmıştır. Araştırma Şanlıurfa II. ürün koşullarında 2012 yılında yürütülmüştür. Güneydoğu Anadolu Bölgesinin tipik karasal iklim özeliklerinin hüküm sürdüğü Şanlıurfa ilinde uzun yıllar verilerine göre yazlar sıcak ve kurak, kışlar ise soğuk ve yağışlı geçmektedir. Denemenin yürütüldüğü aylara ilişkin iklim verileri Çizelge 1' de verilmiștir. Çizelge 1'den görüldüğü gibi Haziran, Temmuz ve Ağustos aylarında sıcaklık $40{ }^{\circ} \mathrm{C}$ 'nin üzerine çıkmış ve nispi nem \%20 ile \%30 arasında değişmiştir. Yaz aylarındaki yağış miktarı ise yok denecek kadar az gerçekleşmiştir.

Deneme alanını bölgede geniş yayılım gösteren Harran toprak serisinde bulunmaktadır. Bu çeşit toprakların ana materyali alüvyon olup killi, derin profilli düz ve düze yakın topraklardır. Tipik kırmızı profilleri kil tekstürlü ve bütün profil oldukça kireçlidir. Alkali olan toprağın $\mathrm{pH}$ düzeyi 7.2 olup, organik madde bakımından fakir, tuzluluk düzeyi az ama kireç oranı (\%59) yüksektir (Dinç ve ark., 1988). Deneme alanından $0-20 \mathrm{~cm}$ derinlikten alınan toprak örneklerinin analiz edilmesiyle elde edilen bazı toprak özellikleri Çizelge 2'de verilmiştir.

Çizelge 1. Denemenin yürütüldüğü aylara ait Şanlıurfa'nın 2012 yılı bazı iklim verileri

\begin{tabular}{lllllll} 
AYLAR & $\begin{array}{l}\text { Ortalama } \\
\text { Sicaklık } \\
\left({ }^{0} \mathrm{C}\right)\end{array}$ & $\begin{array}{l}\text { En Yük. } \\
\text { Sicaklık } \\
\left({ }^{\circ} \mathrm{C}\right)\end{array}$ & $\begin{array}{l}\text { En Düşük } \\
\text { Sicaklık } \\
\left({ }^{\circ} \mathrm{C}\right)\end{array}$ & $\begin{array}{l}\text { Ortalama } \\
\text { Nisbi Nem } \\
(\%)\end{array}$ & $\begin{array}{l}\text { Güneşlenme } \\
\text { süresi } \\
(\text { Saat })\end{array}$ & $\begin{array}{l}\text { Toplam } \\
\text { Yağ1Ş } \\
\left(\mathrm{kg} \mathrm{m}^{2}\right)\end{array}$ \\
\hline Mayıs & 22.4 & 33.2 & 13.0 & 40.8 & 8.6 & 42.3 \\
Haziran & 30.6 & 42.2 & 17.6 & 21.2 & 11.9 & 5.8 \\
Temmuz & 33.3 & 44.2 & 20.0 & 18.8 & 12.0 & 0.2 \\
Ağustos & 32.3 & 42.1 & 22.4 & 29.0 & 10.8 & 0.2 \\
Eylül & 28.4 & 39.9 & 15.6 & 28.0 & 9.6 & 2.0 \\
Ekim & 21.0 & 37.0 & 11.6 & 48.5 & 6.1 & 35.2 \\
Kasım & 14.9 & 26.9 & 7.1 & 65.6 & 4.2 & 68.4 \\
\hline
\end{tabular}

Kaynak: Anonim (2012) 
Farklı Çift Sıra, Dar Sıra ve Tek Sıra Ekim Sistemlerinde Değişik Bitki Yoğunluklarının Mısır Bitkisinin (Zea mays L. indentata) Verim ve Verim Öğelerine Etkisi

Çizelge 2. Deneme alanının bazı fiziksel ve kimyasal özellikleri

\begin{tabular}{lllllllll}
\hline $\begin{array}{l}\text { Derinlik } \\
(\mathrm{cm})\end{array}$ & $\begin{array}{l}\text { Toprak } \\
\text { Bünyesi }\end{array}$ & $\begin{array}{l}\text { Su ile } \\
\text { Doygunluk } \\
(\%)\end{array}$ & $\begin{array}{l}\text { Elektrik } \\
\text { iletkenlik } \\
\begin{array}{l}\text { E.Cx10 } \\
(\mathrm{mhos} / \mathrm{cm})\end{array}\end{array}$ & $\mathrm{pH}$ & $\begin{array}{l}\text { Kireç } \\
\left(\mathrm{CaCO}_{3}\right) \\
(\%)\end{array}$ & $\begin{array}{l}\text { Organik } \\
\text { madde } \\
(\%)\end{array}$ & $\begin{array}{l}\mathrm{P} \\
\left(\mathrm{P}_{2} \mathrm{O}_{5}\right)\end{array}$ & $\begin{array}{l}\mathrm{K} \\
\left(\mathrm{K}_{2} \mathrm{O}\right)\end{array}$ \\
\hline $0-20$ & Killi-Tinli & 68 & 0.39 & 7.40 & 12.3 & 1.74 & 1.9 & 180.7 \\
\hline
\end{tabular}

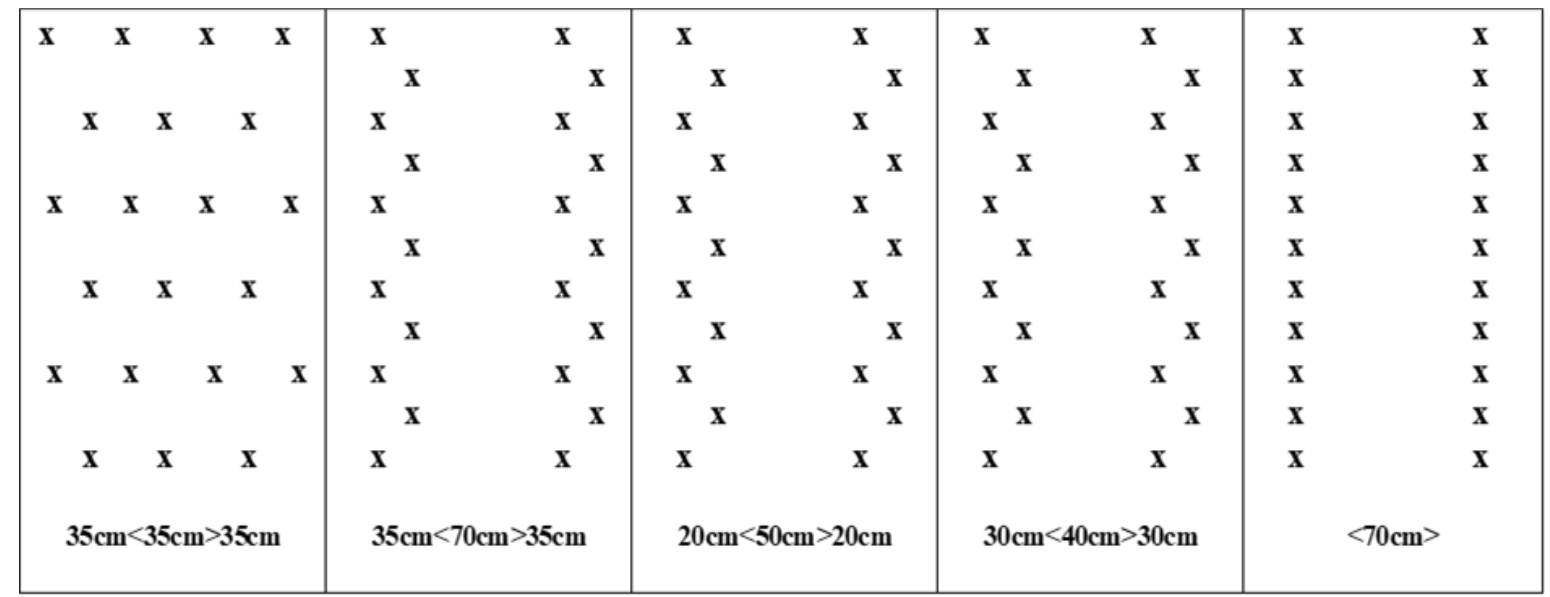

Şekil 1. Farklı ekim sistemi yöntemlerinde bitkilerin tarlada dizaynı

Deneme tesadüf bloklarında bölünmüş parseller deneme deseninde 3 tekerrürlü olarak yürütülmüş̧ür. Ana parsellerde ekim sistemleri, alt parsellerde ise bitki yoğunlukları yer almıştır. Araştırmada 5 farklı ekim sistemi ve 3 farklı bitki yoğunluğu denenmiştir. Ekim sistemleri dar sira $(35-35-35 \mathrm{~cm})$, çift sıra $(70-35-70 \mathrm{~cm})$, çift sıra $(50-20-50 \mathrm{~cm})$, çift sira $(30-40-30 \mathrm{~cm})$ ve tek sira $(70 \mathrm{~cm})$ olarak, bitki yoğunlukları ise 8500 bitki da ${ }^{-1}, 10500$ bitki da $^{-1}$ ve 12500 bitki $\mathrm{da}^{-1}$ olarak oluşturulmuştur. Tek sıra hariç bütün ekim sistemi uygulamalarında yatay mesafede bitkiler zigzag şekilde dizayn edilerek bitki yaşam alanı genişletilmiştir. Farklı ekim sistemi yöntemlerinde bitkilerin tarlada dizaynı Şekil 1'de gösterilmiştir.

Dar sira (35-35-35 cm) ekim sisteminde mevcut uygulanan $70 \mathrm{~cm}$ sira üzeri mesafe ikiye bölünerek sıra araları 35 cm'ye indirilmiş ve 35 cm'de bir bitki sırası bulunacak şekilde ekim yapılmıştır. Bitki yoğunluğunun 8500 bitki da $^{-1}$ olması için sıra üzeri mesafesi $33.6 \mathrm{~cm}, 10500$ bitki da ${ }^{-1}$ olması için $27.2 \mathrm{~cm}, 12500$ bitki da ${ }^{-1}$ olması için $22.8 \mathrm{~cm}$ olacak şekilde ekim yapılmıştır.

Çift sıra (35-70-35) ekim sisteminde $35 \mathrm{~cm}$ sıra aralığı üzerinde çift sıra, ikiz sıralar arasındaki mesafe ise $70 \mathrm{~cm}$ olarak ayarlanmıştır. Bitki yoğunluğunun 8500 bitki da $^{-1}$ olması için sıra üzeri mesafesi $26.8 \mathrm{~cm}, 10500$ bitki da $^{-1}$ olmas1 için $21.8 \mathrm{~cm}, 12500$ bitki da $^{-1}$ olması için 18.3 $\mathrm{cm}$ olacak şekilde ekim yapılmıştır.

Çift sıra (20-50-20) ekim sisteminde, $20 \mathrm{~cm}$ sira aralığı üzerinde çift sıra, ikiz sıralar arasındaki mesafe ise $50 \mathrm{~cm}$ olarak ayarlanmıştır. Bitki yoğunluğunun 8500 bitki da $^{-1}$ olması için sira üzeri mesafesi $33.6 \mathrm{~cm}, 10500$ bitki da $^{-1}$ olmas1 için $27.2 \mathrm{~cm}, 12500$ bitki da $^{-1}$ olması için 22.8 $\mathrm{cm}$ olacak şekilde ekim yapılmıştır.

Çift sıra (30-40-30) ekim sisteminde $30 \mathrm{~cm}$ sira aralığ mesafe ise $40 \mathrm{~cm}$ olarak alınmıştır. Bitki yoğunluğunun 8500 bitki da $^{-1}$ olması için sıra üzeri mesafesi $33.6 \mathrm{~cm}, 10500$ bitki da $^{-1}$ olmas1 için $27.2 \mathrm{~cm}, 12500$ bitki da $^{-1}$ olması için 22.8 cm olarak ekim yapılmıştır.

Çift sıra ve dar sıra aralığının geleneksel ekim karşılaştırmak amacıyla geleneksel olarak mısır yetiştiriciliği yapılan tek sıra ve $70 \mathrm{~cm}$ sıra arası uygulaması da çalışmaya eklenmiştir. Bitki yoğunluğunun 8500 bitki da $^{-1}$ olması için sira üzeri mesafesi $16.8 \mathrm{~cm}$, bitki yoğunluğunun 10500 bitki $\mathrm{da}^{-1}$ olması için sıra üzeri mesafesi $13.6 \mathrm{~cm}$ olarak, bitki yoğunluğunun 12500 bitki 


\section{Farklı Çift Sıra, Dar Sıra ve Tek Sıra Ekim Sistemlerinde Değişik Bitki Yoğunluklarının Mısır Bitkisinin (Zea mays L. indentata) Verim ve Verim Öğelerine Etkisi}

$\mathrm{da}^{-1}$ olması için sıra üzeri mesafesi $11.4 \mathrm{~cm}$ olarak ayarlanmıştır.

Ekimden önce toprak pulluk ve goble disk ile işlenmiş, tapan çekilerek düzleştirilmiş ve ekime hazır hale getirilmiștir. Ekimden önce taban gübresi olarak $10 \mathrm{~kg} \mathrm{da}^{-1}$ saf fosfor ve azot verilerek toprağa karıştırılmıştır. Üst gübre ise mısır bitkileri yaklaşık $50 \mathrm{~cm}$ boylandığında saf olarak $20 \mathrm{~kg} \mathrm{da}^{-1} \mathrm{~N}$ olarak uygulanmıştır.

Her parsel $5 \mathrm{~m}$ uzunluğunda, ekim sistemlerine göre 4 veya 8 siradan meydana gelmiştir. Ekimden önce parsellere markör çekilerek sıra arası mesafeleri belirlenmiştir. Ekimde sıra arası ve sıra üzeri mesafeler belirtilen ekim sistemi uygulamalarına göre yapılmıştır. İstenilen bitki yoğunluğunu sağlamak için her ocağa ikişer tohum olmak üzere misır tohumları $5-6 \mathrm{~cm}$ derinliğe elle ekilmiștir. Çıkıș için yeterli düzeyde nem bulunmadığ 1 için ekimden sonra yağmurlama sulama yapılmıştır. Çimlenmeden sonra tekleme yapılarak dekarda istenilen bitki yoğunluğuna ulaşılmıştır. Gerektikçe mekanik yabancı ot kontrolü yapılmıştır. Yetişme süresi boyunca 8-10 gün arayla sulama yapılmıştır. Araştırmadan elde edilen veriler Jump paket programı kullanılarak varyans analizine ve çoklu karşılaştırma testine tabi tutulmuştur (Yurtsever, 1984).

\section{Bulgular ve Tartışma Bitki boyu (cm)}

Yapılan varyans analizine göre; bitki boyu bakımından ekim sitemleri 0.05 seviyesinde, ekim sistemi $\mathrm{x}$ bitki yoğunluğu interaksiyonu istatistiki olarak 0.01 seviyesinde önemli bulunurken, dekarda bitki yoğunluğunun bitki boyuna etkisi önemsiz bulunmuştur. Farklı ekim sistemlerinde yetiştirilen misır bitkisinin bitki boyuna ait değerler ve ortalamaların karşılaştırılması Çizelge 3'de verilmiştir.

Ekim sistemleri bakımından en düşük bitki boyu $244.22 \mathrm{~cm}$ ile dar sira (35-35-35) ekim sistemi ve en yüksek bitki boyu ise $258.88 \mathrm{~cm}$ ile tek sıra (70-70-70) ekim sisteminden elde edilmiştir. Bitki yoğunluğu bakımından en düşük bitki boyu $247.93 \mathrm{~cm}$ ile 8500 bitki da $^{-1}$ bitki sayısından ve en yüksek bitki boyu ise $253.83 \mathrm{~cm}$ ile 12500 bitki da ${ }^{-1}$ bitki sayısından elde edilmiştir.

Ekim sistemi $\mathrm{x}$ bitki yoğunluğu interaksiyonunda en düşük bitki boyu $228.66 \mathrm{~cm}$ ile dar sira (35-35-35) x 8500 bitki da $\mathrm{da}^{-1}$ kombinasyonundan ve en yüksek bitki boyu $260.00 \mathrm{~cm}$ ile çift sıra (20-50-20) x 8500 bitki da $^{-}$ ${ }^{1}$ ve tek sira (70-70-70) x 10500 bitki da $^{-1}$ ekim sistemlerinden elde edilmişsir.

Araştırma bulgularımıza göre dekarda bitki sayıs1 arttıkça bitki boyunun da arttı̆̆ görülmüştür. Birim alandaki bitki sayısı arttıkça bitkiler 1şık ve besin maddesi için rekabete girerek boylarını artırmaktadır. Araştırma bulgularımızı destekler nitelikte bazı araştırıcılar da benzer sonuçlar bildirmişlerdir (Pagano ve Maddonni, 2007; Bukhsh ve ark., 2008). Gözübenli ve ark. (2004) ile Y1lmaz ve ark. (2008) yüksek bitki sıklıklarında daha uzun bitki boyu değerleri gözlendiğini belirtirken, Turgut (2000) bitki sıklığı üzerine ekim siklığının önemli düzeyde etkili olmadığını bildirmiştir.

\section{Yaprak sayısı (adet bitki ${ }^{-1}$ )}

Yapılan varyans analizine göre; yaprak sayıs1 bakımından ekim sistemi ve bitki yoğunluğu istatistiki olarak $\% 5$ seviyesinde, ekim sistemi x bitki yoğunluğu interaksiyonu ise $\% 1$ seviyesinde önemli bulunmuştur. Farklı ekim sistemlerinde yetiştirilen mısır bitkisinin yaprak sayısı değerleri ve ortalamaların karşılaştırılması Çizelge 4'de verilmiştir.

Ekim sistemleri bakımından en düşük yaprak say1s1 10.66 adet bitki $^{-1}$ ile dar sira (35-35-35) ekim sisteminden, en yüksek yaprak sayısı ise 12.88 adet bitki $^{-1}$ ile tek sira (70-70-70) ekim sistemlerinde elde edilmiştir. Bitki yoğunluğu bakımından yaprak sayısı değerleri 11.40 adet bitki $^{-1}\left(8500\right.$ bitki da $\left.{ }^{-1}\right)$ ile 11.86 adet bitki ${ }^{-1}$ (12500 adet bitki $\left.{ }^{-1}\right)$ arasında değişmiştir. Emeklier ve Kün (1988) bitki yoğunluğu artıkça yaprak sayısının artığını bildirmişlerdir.

Ekim sistemi $\mathrm{x}$ bitki yoğunluğu interaksiyonunda en düşük yaprak sayısı 10.0 adet bitki ${ }^{-1}$ ile dar sira (35-35-35) x 8500 bitki da $^{-}$ ${ }^{1}$ ekim sistemi interaksiyonundan ve en yüksek yaprak sayısı ise 13.0 adet bitki $^{-1}$ ile tek sira (7070-70) x 8500 ve tek sira (70-70-70) x 12500 bitki da ${ }^{-1}$ ekim sistemlerinden elde edilmiş ve tek sira (70-70-70) x 10500 bitki da ${ }^{-1}$ ekim sisteminden istatistiki olarak fark oluşturmadı $\breve{g}_{1}$ kaydedilmiştir. Benzer bulgular bazı araştırıcılar tarafından bildirilmiştir. Abuzar ve ark. (2011) bitki popülasyonu artışının yaprak alanını ve 


\section{Farklı Çift Sıra, Dar Sıra ve Tek Sıra Ekim Sistemlerinde Değişik Bitki Yoğunluklarının Mısır Bitkisinin (Zea mays L. indentata) Verim ve Verim Öğelerine Etkisi}

yaprak sayısını artırdı̆̆ını, bunun da net asimilasyon oranını artırarak tane veriminde artış sağladığını bildirmiştir. Bruns ve ark.
(2012) yaprak sayısının ve yaprak alan indeksinin çift sırada, tek sıraya göre daha yüksek bulunduğunu bildirmişlerdir.

Çizelge 3. Farklı ekim sistemleri ile değişik bitki yoğunluğunun mısır bitkisinin bitki boyuna etkisi

\begin{tabular}{lllll}
\multirow{2}{*}{ Ekim sistemi } & \multicolumn{4}{c}{ Bitki yoğunluğu (bitki da ${ }^{-1}$ ) } \\
\cline { 2 - 5 } & 8500 & 10500 & 12500 & Ortalama \\
\hline Dar sıra (35-35-35) & $228.66 \mathrm{c}^{*}$ & $250.66 \mathrm{ab}$ & $253.33 \mathrm{ab}$ & $244.22 \mathrm{~B}$ \\
Çift sıra (35-70-35) & $249.66 \mathrm{ab}$ & $251.66 \mathrm{ab}$ & $255.00 \mathrm{ab}$ & $252.11 \mathrm{AB}$ \\
Çift sıra (20-50-20) & $260.00 \mathrm{a}$ & $248.83 \mathrm{ab}$ & $249.83 \mathrm{ab}$ & $252.88 \mathrm{AB}$ \\
Çift sıra (30-40-30) & $244.33 \mathrm{ab}$ & $253.50 \mathrm{ab}$ & $251.33 \mathrm{ab}$ & $249.72 \mathrm{AB}$ \\
Tek sıra (70-70-70) & $257.00 \mathrm{ab}$ & $260.00 \mathrm{a}$ & $259.66 \mathrm{a}$ & $258.88 \mathrm{~A}$ \\
Ortalama & 247.93 & 252.93 & 253.83 & \\
LSD ekim sistemi:13.41 & LSD bitki yoğunluğu:5.23 LSD ekim sistemi x bitki yoğunluğu:14.69 \\
\hline
\end{tabular}

* : Aynı sütunda aynı harfle ifade edilen değerler arasında 0.05 seviyesinde önemli farklılık yoktur.

Çizelge 4. Farklı ekim sistemleri ile değişik bitki yoğunluğunun mısır bitkisinin yaprak sayısına etkisi

\begin{tabular}{lllll}
\hline \multirow{2}{*}{ Ekim sistemi } & \multicolumn{4}{c}{ Bitki yoğunluğu (bitki da ${ }^{-1}$ ) } \\
\cline { 2 - 5 } & 8500 & 10500 & 12500 & Ortalama \\
\hline Dar sıra (35-35-35) & $10.00 \mathrm{c}^{*}$ & $11.00 \mathrm{bc}$ & $11.00 \mathrm{bc}$ & $10.66 \mathrm{C}$ \\
Çift sıra (35-70-35) & $11.00 \mathrm{bc}$ & $11.33 \mathrm{~b}$ & $12.00 \mathrm{ab}$ & $11.44 \mathrm{BC}$ \\
Çift sıra (20-50-20) & $12.00 \mathrm{ab}$ & $11.33 \mathrm{~b}$ & $11.33 \mathrm{~b}$ & $11.55 \mathrm{BC}$ \\
Çift sıra (30-40-30) & $11.00 \mathrm{bc}$ & $12.66 \mathrm{a}$ & $12.00 \mathrm{ab}$ & $11.88 \mathrm{AB}$ \\
Tek sıra (70-70-70) & $13.00 \mathrm{a}$ & $12.66 \mathrm{a}$ & $13.00 \mathrm{a}$ & $12.88 \mathrm{~A}$ \\
Ortalama & $11.40 \mathrm{~B}$ & $11.80 \mathrm{~A}$ & $11.86 \mathrm{~A}$ & \\
LSD ekim sistemi:1.06 & LSD bitki yoğunluğu : 0.33 & LSD ekim sistemi x bitki yoğunluğu:1.06 \\
\hline
\end{tabular}

*: Aynı sütunda aynı harfle ifade edilen değerler arasında 0.05 seviyesinde önemli farklılık yoktur.

\section{Koçan kalınlığı (mm)}

Yapılan varyans analizine göre; koçan kalınlığı bakımından ekim sistemi ve bitki yoğunluğu istatistiki olarak 0.01 ve ekim sistemi x bitki yoğunluğu interaksiyonu istatistiki olarak 0.05 seviyesinde önemli bulunmuştur. Ekim sistemleri bakımından en düşük koçan kalınlığı $39.00 \mathrm{~mm}$ ile çift sıra (30-40-30) ekim sistemi ve en yüksek koçan çapı ise $45.55 \mathrm{~mm}$ ile tek sıra (70-70-70) ekim sisteminden elde edilmiştir (Çizelge 5).

Araştırma bulgularımıza göre çift sıra ekim yönteminde koçan çapının azaldığı görülmüştür. Bulgularımızı destekler nitelikte Eskandarnejad ve ark. (2013) çift sıra yönteminde koçan uzunluğunun azaldığını bildirmişlerdir.

Bitki yoğunluğu bakımından koçan kalınlığı $40.13 \mathrm{~mm}$ ile (12500 bitki da ${ }^{-1}$ bitki) $44.86 \mathrm{~mm}$ (8500 bitki $\mathrm{da}^{-1}$ bitki) arasında değişmiştir. Bulgularımıza benzer olarak bazı araştırıcılar bitki yoğunluğu artıkça koçan kalınlığının azaldığını bildirmişlerdir (Alıcı, 2005; Saruhan ve Şireli, 2005; Yılmaz ve ark., 2005; Şirikçi, 2006). Ekim sistemi $\mathrm{x}$ bitki yoğunluğu interaksiyonunda ise en düşük koçan kalınlığ 1 $36.33 \mathrm{~mm}$ ile çift sıra (30-40-30) x 12500 bitki $\mathrm{da}^{-1}$ ekim sisteminden, en yüksek koçan kalınlığ 1 ise $47.33 \mathrm{~mm}$ ile tek sira (70-70-70) x 8500 bitki $\mathrm{da}^{-1}$ ekim sisteminden elde edilmiştir. Liu ve ark. (2004) çift sıra ekimleriyle sağlanan aşırı popülasyon yoğunluklarında koçan kalınlığı değerlerinin azaldığını bildirmişlerdir.

\section{Koçan uzunluğu (cm)}

Koçan uzunluğu bakımından ekim sistemi, bitki yoğunluğu ve ekim sistemi x bitki yoğunluğu interaksiyonu istatistiki olarak \%1 seviyesinde önemli bulunmuştur. Farklı ekim sistemlerinde yetiştirilen mısır bitkisinin koçan uzunluğuna ait değerler ve ortalamaların karşılaştırılması Çizelge 6' da verilmiştir. 


\section{Farklı Çift Sıra, Dar Sıra ve Tek Sıra Ekim Sistemlerinde Değişik Bitki Yoğunluklarının Mısır Bitkisinin (Zea mays L. indentata) Verim ve Verim Öğelerine Etkisi}

Ekim sistemleri bakımından koçan uzunluğu değerleri $15.46 \mathrm{~cm}$ (çift sıra 30-40-30 ekim sistemi) ile $18.93 \mathrm{~cm}$ (tek sira 70-70-70 ekim sistemi) arasında değişmiştir.

Araştırma bulgularımıza göre çift sıra ekim yönteminde koçan boyunun azaldığ görülmüştür.

Araştırma bulgularıyla benzer olarak Eskandarnejad ve ark. (2013) çift sıra ekim yönteminde koçan uzunluğu değerinin azaldığını belirtmişlerdir.

Bitki yoğunluğu bakımından en düşük koçan uzunluğu $16.50 \mathrm{~cm}$ ile 12500 bitki da $^{-1}$ bitki yoğunluğundan, en yüksek koçan uzunluğu ise
$18.43 \mathrm{~cm}$ ile 8500 bitki da $^{-1}$ bitki yoğunluğundan elde edilmiştir. Dekarda bitki sayısı artıkça koçan boyunun azaldığı belirlenmiştir. Bulgularımızla paralele olarak bazı araştırıcılar artan bitki yoğunluklarında koçan uzunluğunun azaldığını belirtmişlerdir (Turgut, 2000, Sangoi ve ark., 2002; Saruhan ve Şireli, 2005; Yılmaz ve ark., 2005; Şirikçi, 2006).

Ekim sistemi $\mathrm{x}$ bitki yoğunluğu interaksiyonunda, en düşük koçan uzunluğu $14.43 \mathrm{~cm}$ ile çift sıra (30-40-30) x 12500 bitki da $^{-}$ ${ }^{1}$ ekim sisteminden, en yükssek koçan uzunluğu ise $20.66 \mathrm{~cm}$ ile tek s1ra (70-70-70) x 8500 bitki $\mathrm{da}^{-1}$ ekim sisteminden elde edilmiştir.

Çizelge 5. Farklı ekim sistemleri ile değişik bitki yoğunluğunun mısır bitkisinin koçan kalınlığına etkisi

\begin{tabular}{lllll}
\hline \multirow{2}{*}{ Ekim sistemi } & \multicolumn{4}{c}{ Bitki yoğunluğu (bitki da $\left.{ }^{-1}\right)$} \\
\cline { 2 - 4 } & 8500 & 10500 & 12500 & Ortalama \\
\hline Dar sıra (35-35-35) & $44.33 \mathrm{de} *$ & $42.33 \mathrm{fg}$ & $40.33 \mathrm{~h}$ & $42.33 \mathrm{C}$ \\
Çift sıra (35-70-35) & $46.00 \mathrm{bc}$ & $45.00 \mathrm{~cd}$ & $42.00 \mathrm{~g}$ & $44.33 \mathrm{~B}$ \\
Çift sıra (20-50-20) & $44.66 \mathrm{~d}$ & $43.33 \mathrm{ef}$ & $39.00 \mathrm{i}$ & $42.33 \mathrm{C}$ \\
Çift sıra (30-40-30) & $42.00 \mathrm{~g}$ & $38.66 \mathrm{i}$ & $36.33 \mathrm{j}$ & $39.00 \mathrm{D}$ \\
Tek sıra (70-70-70) & $47.33 \mathrm{a}$ & $46.33 \mathrm{ab}$ & $43.00 \mathrm{fg}$ & $45.55 \mathrm{~A}$ \\
Ortalama & $44.86 \mathrm{~A}$ & $43.13 \mathrm{~B}$ & $40.13 \mathrm{C}$ &
\end{tabular}

LSD ekim sistemi:1.15 LSD bitki yoğunluğu : $0.49 \quad$ LSD ekim sistemi x bitki yoğunluğu:1.31

* : Aynı sütunda aynı harfle ifade edilen değerler arasında 0.05 seviyesinde önemli farklılık yoktur.

Çizelge 6. Farklı ekim sistemleri ile değişik bitki yoğunluğunun mısır bitkisinin koçan uzunluğuna etkisi

\begin{tabular}{lllll}
\hline \multirow{2}{*}{ Ekim sistemi } & \multicolumn{4}{c}{ Bitki yoğunluğu (bitki da ${ }^{-1}$ ) } \\
\cline { 2 - 5 } & 8500 & 10500 & 12500 & Ortalama \\
\hline Dar sıra (35-35-35) & $18.10 \mathrm{de}^{*}$ & $17.16 \mathrm{fg}$ & $16.76 \mathrm{gh}$ & $17.34 \mathrm{~B}$ \\
Çift sıra (35-70-35) & $19.36 \mathrm{~b}$ & $18.70 \mathrm{c}$ & $17.93 \mathrm{de}$ & $18.66 \mathrm{~A}$ \\
Çift sıra (20-50-20) & $17.53 \mathrm{ef}$ & $16.43 \mathrm{~h}$ & 15.63 & $16.53 \mathrm{C}$ \\
Çift sıra (30-40-30) & $16.50 \mathrm{~h}$ & $15.46 \mathrm{1}$ & $14.43 \mathrm{j}$ & $15.46 \mathrm{D}$ \\
Tek sıra (70-70-70) & $20.66 \mathrm{a}$ & $18.36 \mathrm{~cd}$ & $17.76 \mathrm{e}$ & $18.93 \mathrm{~A}$ \\
Ortalama & $18.43 \mathrm{~A}$ & $17.22 \mathrm{~B}$ & $16.50 \mathrm{C}$ & \\
LSD ekim sistemi:0.44 & LSD bitki yoğunluğu : 0.24 & LSD ekim sistemi x bitki yoğunluğu : 0.57 \\
\hline
\end{tabular}

* : Aynı sütunda aynı harfle ifade edilen değerler arasında 0.05 seviyesinde önemli farklılık yoktur.

Koçanda tane sayısı (adet koçan ${ }^{-1}$ )

Yapılan varyans analizine göre; koçanda tane sayısı bakımından ekim sistemi, bitki yoğunluğu ve ekim sistemi x bitki yoğunluğu interaksiyonu istatistiki olarak 0.01 seviyesinde önemli bulunmuştur. Farklı ekim sistemlerinde yetiştirilen mısır bitkisinin koçanda tane sayısı ait değerler ve ortalamaların karşılaştırılması Çizelge 7'de verilmiştir. 


\section{Farklı Çift Sıra, Dar Sıra ve Tek Sıra Ekim Sistemlerinde Değişik Bitki Yoğunluklarının Mısır Bitkisinin (Zea mays L. indentata) Verim ve Verim Öğelerine Etkisi}

Çizelge 7. Farklı ekim sistemleri ile değișik bitki yoğunluğunun mısır bitkisinin koçan tane sayısına etkisi

\begin{tabular}{lllll}
\multicolumn{2}{c}{ Ekim sistemi } & \multicolumn{4}{c}{ Bitki yoğunluğu (bitki da ${ }^{-1}$ ) } \\
\cline { 2 - 5 } & 8500 & 10500 & 12500 & Ortalama \\
\hline Dar sıra (35-35-35) & $513.33 \mathrm{~b} *$ & $426.66 \mathrm{~cd}$ & $320.00 \mathrm{f}$ & $420.00 \mathrm{~B}$ \\
Çift sıra (35-70-35) & $550.00 \mathrm{a}$ & $513.33 \mathrm{~b}$ & $406.66 \mathrm{~d}$ & $490.00 \mathrm{~A}$ \\
Çift sıra (20-50-20) & $433.33 \mathrm{c}$ & $413.33 \mathrm{~cd}$ & $308.66 \mathrm{fg}$ & $385.11 \mathrm{C}$ \\
Çift sıra (30-40-30) & $426.66 \mathrm{~cd}$ & $354.00 \mathrm{e}$ & $287.00 \mathrm{~g}$ & $355.88 \mathrm{D}$ \\
Tek sıra (70-70-70) & $566.66 \mathrm{a}$ & $512.00 \mathrm{~b}$ & $430.00 \mathrm{~cd}$ & $502.88 \mathrm{~A}$ \\
Ortalama & $498.00 \mathrm{~A}$ & $443.86 \mathrm{~B}$ & $350.46 \mathrm{C}$ & \\
LSD ekim sistemi:22.39 & LSD bitki yoğunluğu : 8.45 LSD ekim sistemi x bitki yoğunluğu : 24.18 \\
\hline
\end{tabular}

* : Aynı sütunda aynı harfle ifade edilen değerler arasında 0.05 seviyesinde önemli farklılık yoktur.

Ekim sistemleri bakımından koçanda tane sayıs1 değerleri 355.88 adet koçan $^{-1}$ ile (çift sıra 30-4030 ekim sistemi) 502.88 adet koçan $^{-1}$ (tek sıra 70-70-70 ekim sistemi) arasında değișmiștir.

Bitki yoğunluğu bakımından en düşük koçanda tane sayıs 350.46 adet koçan $^{-1}$ ile 12500 bitki da ${ }^{1}$ bitki sayısından, en yüksek koçanda tane sayısı ise 498.00 adet koçan $^{-1}$ ile 8500 bitki da $^{-1}$ bitki sayısından elde edilmiştir. Dekardaki bitki sayısı azaldıkça koçanda tane sayısının arttığı, bitki sayısının artmasıyla ise koçanda tane sayısı değerlerinin azaldığı tespit edilmiştir. Bitki yoğunluğu arttıkça koçan kalınlığının ve koçan uzunluğunun azalması nedeniyle koçanda tane sayısı da azalmaktadır. Dekarda bitki sayısının artmasiyla birlikte birim alandaki besin maddesinin alımı açısından bitkiler arasında rekabet oluşmakta ve bunun sonucunda koçandaki tane sayısı değerlerinde azalma gözlenmektedir.

Benzer şekilde bazı araştırıcılar bitki yoğunluğu azaldıkça, koçanda tane sayısında artış olduğunu bildirilmiştir (Alıc1, 2005; Amaral Filho ve ark., 2005; Zeidan ve ark., 2006; Çarpıc1, 2009).
Artan bitki yoğunluklarında koçanda tane sayısının azaldığı Sangoi ve ark. (2002) ve Şirikçi (2006) tarafindan belirtilmiştir.

Ekim sistemi $\mathrm{x}$ bitki yoğunluğu interaksiyonunu incelediğimizde, en düşük koçanda tane sayısı

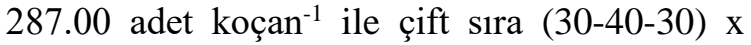
12500 bitki da ${ }^{-1}$ ekiminden, en yüksek koçanda tane sayısı değeri ise 566.66 adet koçan ${ }^{-1}$ ile tek sira (70-70-70) x 8500 bitki da $^{-1}$ ekim sisteminden elde edilmiştir. Çift sıra ekim yönteminde koçanda tane sayısı değerinin azaldığı belirtilmektedir (Eskandarnejad ve ark., 2013; Liu ve ark., 2004).

\section{Koçanda tane ağırlığı (g)}

Varyans analizine göre; koçanda tane ağırlığ 1 bakımından ekim sistemi ve bitki yoğunluğu istatistiki olarak 0.01 ve ekim sistemi x bitki yoğunluğu interaksiyonu istatistiki olarak 0.05 seviyesinde önemli bulunmuştur. Farklı ekim sistemlerinde yetiştirilen misır bitkisinin koçanda tane ağırlığına ait değerler ve ortalamaların karşılaştırılması Çizelge 8'de verilmiştir.

Çizelge 8. Farklı ekim sistemleri ile değişik bitki yoğunluğunun mısır bitkisinin koçanda tane ağırlığg (g) üzerine etkisi ve oluşan LSD grupları.

\begin{tabular}{llllc}
\hline \multirow{2}{*}{ Ekim sistemi } & \multicolumn{4}{c}{ Bitki yoğunluğu (bitki da ${ }^{-1}$ ) } \\
\cline { 2 - 4 } & 8500 & 10500 & 12500 & Ortalama \\
\hline Dar sıra (35-35-35) & $168.96 \mathrm{ab}^{*}$ & $144.73 \mathrm{c}$ & $119.73 \mathrm{~d}$ & $144.47 \mathrm{C}$ \\
Çift sıra (35-70-35) & $173.86 \mathrm{a}$ & $153.53 \mathrm{c}$ & $126.93 \mathrm{~d}$ & $151.44 \mathrm{BC}$ \\
Çift sıra (20-50-20) & $168.00 \mathrm{ab}$ & $150.76 \mathrm{c}$ & $145.53 \mathrm{c}$ & $154.76 \mathrm{~B}$ \\
Çift sıra (30-40-30) & $115.36 \mathrm{~d}$ & $93.56 \mathrm{e}$ & $74.83 \mathrm{f}$ & $94.58 \mathrm{D}$ \\
Tek sıra (70-70-70) & $174.56 \mathrm{a}$ & $168.10 \mathrm{ab}$ & $157.30 \mathrm{bc}$ & $166.65 \mathrm{~A}$ \\
Ortalama & $160.15 \mathrm{~A}$ & $142.14 \mathrm{~B}$ & $124.86 \mathrm{C}$ & \\
LSD ekim sistemi:9.34 & LSD bitki yoğunluğu : 6.06 LSD ekim sistemi x bitki yoğunluğu : 13.63 \\
\hline
\end{tabular}

* : Aynı sütunda aynı harfle ifade edilen değerler arasında 0.05 seviyesinde önemli farklılık yoktur. 


\section{Farklı Çift Sıra, Dar Sıra ve Tek Sıra Ekim Sistemlerinde Değişik Bitki Yoğunluklarının Mısır Bitkisinin (Zea mays L. indentata) Verim ve Verim Öğelerine Etkisi}

Ekim sistemleri bakımından en düşük koçanda tane ağırlığ $194.58 \mathrm{~g}$ ile çift sıra (30-40-30) ekim sistemi ve en yüksek koçanda tane ağırlı̆̆ $166.65 \mathrm{~g}$ ile tek sira (70-70-70) ekim sistemlerinde elde edilmiștir. Dar ve çift sıra ekimlerinde artan bitki yoğunluğuna paralel olarak koçanda tane ağırlığı değerlerinde azalma görülmüştür. Benzer şekilde Liu ve ark. (2004) çift sıra ekimleriyle sağlanan aşırı bitki yoğunluklarında koçanda tane ağırlığı değerlerinin azaldığını bildirmişlerdir.

Araştırma bulgularımıza göre dar sıra ekim sistemine göre çift sıra ekim yönteminde koçanda tane ağırlığının arttığı görülmüştür.

Bitki yoğunluğu bakımından en düşük koçanda tane ağırlığı $124.86 \mathrm{~g}$ ile 12500 bitki da $^{-1}$ ekim sıklığından ve en yüksek koçanda tane ağırlığı ise $160.15 \mathrm{~g}$ ile 8500 bitki da $^{-1}$ ekim sıklığından elde edilmiştir.

Düşük bitki yoğunluğunda daha yüksek, yüksek bitki yoğunluğunda ise daha düşük koçanda tane ağırlığ 1 değerleri elde edilmiştir. Sangoi ve ark. (2002) ve Şirikçi (2006) artan bitki yoğunluklarında koçanda tane ağırlığının azaldığını belirtmişlerdir.

En düşük koçanda tane ağırlığı $74.83 \mathrm{~g}$ ile çift sira (30-40-30) x 12500 bitki da $^{-1}$ ekim sistemi interaksiyonundan, en yüksek koçanda tane ağırlığ1 ise $174.56 \mathrm{~g}$ ile tek sira (70-70-70) $\mathrm{x}$ 8500 bitki da $^{-1}$ ekim sistemlerinden elde edilmiş ve çift sıra (35-70-35) x 8500 bitki da $^{-1}$ ekim sıklığı ile aralarında istatistiki olarak fark oluşmadığı kaydedilmiştir.

Bin tane ağırlığı (g)

Bin tane ağırlığı bakımından ekim sistemi, bitki yoğunluğu, ekim sistemi $\mathrm{x}$ bitki yoğunluğu interaksiyonu istatistiki olarak \%1 seviyesinde önemli bulunmuştur. Farklı ekim sistemlerinde yetiştirilen mısır bitkisinin bin tane ağırlı̆̆ına ait değerler ve ortalamaların karşılaştırılması Çizelge 9'da verilmiştir.

Ekim sistemleri bakımından bin tane ağırlığ değerleri $260.22 \mathrm{~g}$ (çift sira 30-40-30 ekim sistemi) ile $317.44 \mathrm{~g}$ (tek sira 70-70-70 ekim sistemi) arasında değişmiştir.

Bitki yoğunluğu bakımından en düşük bin tane ağırlığı $263.66 \mathrm{~g}$ ile 12500 bitki da ${ }^{-1}$ ekim sıklığından ve en yüksek bin tane ağırlığ 1 ise $329.73 \mathrm{~g}$ ile 8500 bitki da $^{-1}$ ekim sıklığından elde edilmiştir.

Çalışmamızda düşük bitki yoğunluğunda bin tane ağırlığının arttığı tespit edilmiştir. Bitki sayısı arttıkça bin tane ağırlığının azaldığ gözlenmiștir.

Çift sira (30-40-30) x 12500 bitki da $^{-1}$ ekim sistemi interaksiyonundan $232.33 \mathrm{~g}$ ile en düşük bin tane ağırlığı, tek sira (70-70-70) x 8500 bitki $\mathrm{da}^{-1}$ ekim sistemlerinden interaksiyonundan ise $361.66 \mathrm{~g}$ ile en yüksek bin tane ağırlığı elde edilmiştir.

Birim alanda daha az bitki yoğunluğu olduğunda, bitkiler topraktaki mevcut bitki besin elementlerini daha fazla kullanması sonucunda koçandaki taneler daha iri olmakta, bunun neticesinde ise bin tane ağırlığı artmaktadır.

Bulgularımızı destekler nitelikte benzer sonuçlar bazı araștırıcılar tarafından da bildirilmiștir (Çokkızıın, 2002, Sharar ve ark., 2002; Mahbubul ve ark., 2003; Zeidan ve ark., 2006). Şirikçi (2006) ve Bruns ve ark. (2012) artan bitki yoğunluklarında bin tane ağırlığının azaldığını belirtmişlerdir.

Çizelge 9. Farklı ekim sistemleri ile değişik bitki yoğunluğunun mısır bitkisinin bin tane ağırlığına etkisi

\begin{tabular}{lllll}
\hline \multirow{2}{*}{ Ekim sistemi } & \multicolumn{4}{c}{ Bitki yoğunluğu (bitki da ${ }^{-1}$ ) } \\
\cline { 2 - 5 } & 8500 & 10500 & 12500 & Ortalama \\
\hline Dar sıra (35-35-35) & $343.00 \mathrm{~b}^{*}$ & $285.00 \mathrm{f}$ & $263.33 \mathrm{~g}$ & $297.11 \mathrm{C}$ \\
Çift sıra (35-70-35) & $323.66 \mathrm{c}$ & $309.33 \mathrm{de}$ & $289.66 \mathrm{f}$ & $307.55 \mathrm{~B}$ \\
Çift sira (20-50-20) & $317.66 \mathrm{~cd}$ & $266.66 \mathrm{~g}$ & $248.66 \mathrm{~h}$ & $277.66 \mathrm{D}$ \\
Çift sıra (30-40-30) & $302.66 \mathrm{e}$ & $245.66 \mathrm{~h}$ & 232.33 & $260.22 \mathrm{E}$ \\
Tek sira (70-70-70) & $361.66 \mathrm{a}$ & $306.33 \mathrm{de}$ & $284.33 \mathrm{f}$ & $317.44 \mathrm{~A}$ \\
Ortalama & $329.73 \mathrm{~A}$ & $282.60 \mathrm{~B}$ & $263.66 \mathrm{C}$ & \\
LSD ekim sistemi:9.13 & LSD bitki yoğunluğu : 4.81 LSD ekim sistemi x bitki yoğunluğu :11.67 \\
\hline
\end{tabular}

* : Aynı sütunda aynı harfle ifade edilen değerler arasında 0.05 seviyesinde önemli farklılık yoktur. 


\section{Farklı Çift Sıra, Dar Sıra ve Tek Sıra Ekim Sistemlerinde Değişik Bitki Yoğunluklarının Mısır Bitkisinin (Zea mays L. indentata) Verim ve Verim Öğelerine Etkisi}

\section{Tane verimi $\left(\mathrm{kg} \mathrm{da}^{-1}\right)$}

Varyans analizine göre; tane verimi bakımından ekim sistemi, bitki yoğunluğu, ekim sistemi x bitki yoğunluğu interaksiyonu istatistiki olarak 0.01 seviyesinde önemli bulunmuştur.

En düşük tane verimi $848.11 \mathrm{~kg} \mathrm{da}^{-1}$ ile çift sira (30-40-30) ekim sisteminden, en yüksek tane verimi ise $1261.55 \mathrm{~kg} \mathrm{da}^{-1}$ ile çift sıra (35-70-35) ekim sistemlerinde elde edilmiştir. Çift sıra (3570-35) ekim sistemi geleneksel ekim sistemi olan tek sira (70-70-70) ekim sisteminden daha yüksek tane verimi vermiştir. Dar sıra (35-3535) ekim sistemi ise çift sıra (35-70-35) ekim sisteminden sonra tane verimi yönünden ikinci sırada yer almış, tek sıra (70-70-70) ekim sistemi üçüncü sırada, çift sıra (30-40-30) ekim sistemi dördüncü ve çift sıra (30-40-30) ekim sistemi ise sonuncu sırada yer almıştır. Araştırma bulgularımıza göre çift sıra ekim yönteminde 35 $\mathrm{cm}$ ve üzerindeki sira arasi mesafede tane veriminin arttı̆̆1 görülmüştür (Çizelge 10). Amerika birleşik devletlerinde dar sira ile ilgili yapılan 2 yıllık çalışmaların \% 69.8 oranında tane verimi bakımından olumlu sonuç alındığını, $\% 30.02$ oranında ise olumsuz sonuç alındığı belirtilmiştir (Anonim, 2015a ve 2015b).

Gözübenli (2010)'da, Hatay koşullarında yapılan bir araştırmada, çift sıra ve dar sıra mısırda, geleneksel geniş sıra aralığına göre daha iyi verim elde edildiği bildirilmiştir. Araştırma bulgularımızı destekler nitelikte çift sıra ekimlerinden tek sıraya göre daha yüksek verim elde edildiği başka araştırıcılar tarafından da bildirilmektedir (Liu ve ark., 2004; Bruns ve ark., 2012; Eskandarnejad ve ark., 2013).

Stahl ve Bau (2009) Amerika Birleşik Devletleri'nin Minnesota eyaletinde 5 y1 boyunca yürüttükleri bir çalışmada; geniş sıra aralığına göre dar sıra aralığının güney Minnesota'da farklılık göstermediğini, batı-orta Minnesota'da \%5, kuzeybatı Minnesota'da \%16 verim artışı sağlandığını bildirmişlerdir. Bulgularımızın aksine Robles ve ark. (2012) farklı bitki yoğunlukları ve farklı hibrit mısır çeşitleri ile Batı-Orta Hindistan'da yaptıkları çalışmada, tüm bitki yoğunluğu ve hibrit mısır çeşitlerinde çift sıra ve tek sıra arasında verim açısından bir farklılık olmadığını bildirmişlerdir. Gregg ve ark. (1998) dar sıra aralığının mısır bitkisinde tane verimini yükseltmediğini, fakat bitki popülasyonun ve mevcut yabanc1 ot görünümünün etkili faktör olduğunu bildirmişlerdir.

Bitki yoğunluğu bakımından tane verimi $1015.46 \mathrm{~kg} \mathrm{da}^{-1}\left(12500 \mathrm{bitki} \mathrm{da}^{-1}\right)$ ile $1100.40 \mathrm{~kg}$ $\mathrm{da}^{-1}$ (10500 bitki $\left.\mathrm{da}^{-1}\right)$ arasında değişmiştir. 10500 bitki da $^{-1}$ bitki yoğunluğu diğerlerinden daha yüksek tane verimi elde edilmesine sebep olmuştur. Aşırı bitki yoğunluğunda bitkiler 1şık ve su ve besin elementlerine karşı birbirleriyle rekabete girmekte ve bu durumda da tane verimi azalmaktadır. Ayrıca aşırı bitki yoğunluğunda her bir bitki ürün oluşturabilmek için önce kök, sap, yaprak, çiçek gibi organlar oluşturmak için su ve besin maddesi kaynaklarını harcamaktadır. Oysaki kullanılan bu kaynaklar biraz daha düşük bitki yoğunluklarında bu tip organların gelişimine kullanılmadan mevcut bitkiler tarafindan doğrudan kuru madde birikimine dönüşerek tane verimini artırabilmektedir. Otegui ve Andrade (2000) optimum üstünde olan bitki yoğunluğunda asimilasyon için özellikle çiçeklenme periyodunda bitkiler arasında rekabetin arttığını belirtmişlerdir. Çeşit farklılıklarıyla değişmekle birlikte aşırı popülasyon yoğunluğunun olmadığı koşullarda tane veriminin artığı bildirilmiştir (Widdicombe ve Thelen, 2002).

Andrade ve ark. (2002)'de, Arjantin'de yaptıkları bir araştırmada bitki sayısı azaldığında tane veriminin yükseldiğini belirtirken, Saberali (2007) yüksek misır yoğunluğunda misırda toplam kuru ağırlık ve ürün büyüme oranında artış görüldüğünü belirtmiştir. Artan bitki yoğunluklarında verimin arttığ1 belirtilmiştir (Sangoi ve ark. 2002; Şirikçi, 2006). Bazı araştırıcılar bitki yoğunluğu ile ürün büyüme oranı arasında önemli bir ilişki olduğunu, yapılan çalışmalarda artan bitki yoğunluğunun ürün miktarını artırdığını vurgulamışlardır (Pagano ve Maddonni, 2007; Bukhsh ve ark., 2008). Ekim sistemi $\mathrm{x}$ bitki yoğunluğu interaksiyonunda en düşük tane verimi 799.00 $\mathrm{kg} \mathrm{da}^{-1}$ ile çift sıra (30-40-30) x 12500 bitki da $^{-1}$ ekim sisteminden, en yüksek tane verimi ise $1425.66 \mathrm{~kg} \mathrm{da}^{-1}$ ile çift sıra (35-70-35) x 10500 bitki da ${ }^{-1}$ ekim sisteminden elde edilmiştir (Şekil 2). 
Farklı Çift Sıra, Dar Sıra ve Tek Sıra Ekim Sistemlerinde Değişik Bitki Yoğunluklarının Mısır Bitkisinin (Zea mays L. indentata) Verim ve Verim Öğelerine Etkisi

Çizelge 10. Farklı ekim sistemleri ile değişik bitki yoğunluğunun mısır bitkisinin tane verimine etkisi

\begin{tabular}{|c|c|c|c|c|}
\hline \multirow{2}{*}{ Ekim sistemi } & \multicolumn{4}{|c|}{ Bitki yoğunluğu (bitki da ${ }^{-1}$ ) } \\
\hline & 8500 & 10500 & 12500 & Ortalama \\
\hline Dar sira (35-35-35) & $1087.66 \mathrm{cde}$ & $1250.00 \mathrm{~b}^{*}$ & $1145.00 \mathrm{c}$ & $1160.88 \mathrm{~B}$ \\
\hline Çift sıra (35-70-35) & $1108.00 \mathrm{~cd}$ & $1425.66 \mathrm{a}$ & $1251.00 \mathrm{~b}$ & $1261.55 \mathrm{~A}$ \\
\hline Çift sıra (20-50-20) & $1007.66 \mathrm{f}$ & $924.33 \mathrm{~g}$ & 864.33 gh1 & $932.11 \mathrm{D}$ \\
\hline Çift sıra (30-40-30) & $908.00 \mathrm{gh}$ & 837.33 h1 & 799.001 & $848.11 \mathrm{E}$ \\
\hline Tek sira $(70-70-70)$ & $1100.66 \mathrm{~cd}$ & $1064.66 \mathrm{def}$ & 1018.00 ef & $1061.11 \mathrm{C}$ \\
\hline Ortalama & $1042.40 \mathrm{~B}$ & $1100.40 \mathrm{~A}$ & $1015.46 \mathrm{~B}$ & \\
\hline LSD ekim sistemi:51.19 & \multicolumn{4}{|c|}{ LSD bitki yoğunluğu : 32.11 LSD ekim sistemi x bitki yoğunluğu :72.96 } \\
\hline
\end{tabular}

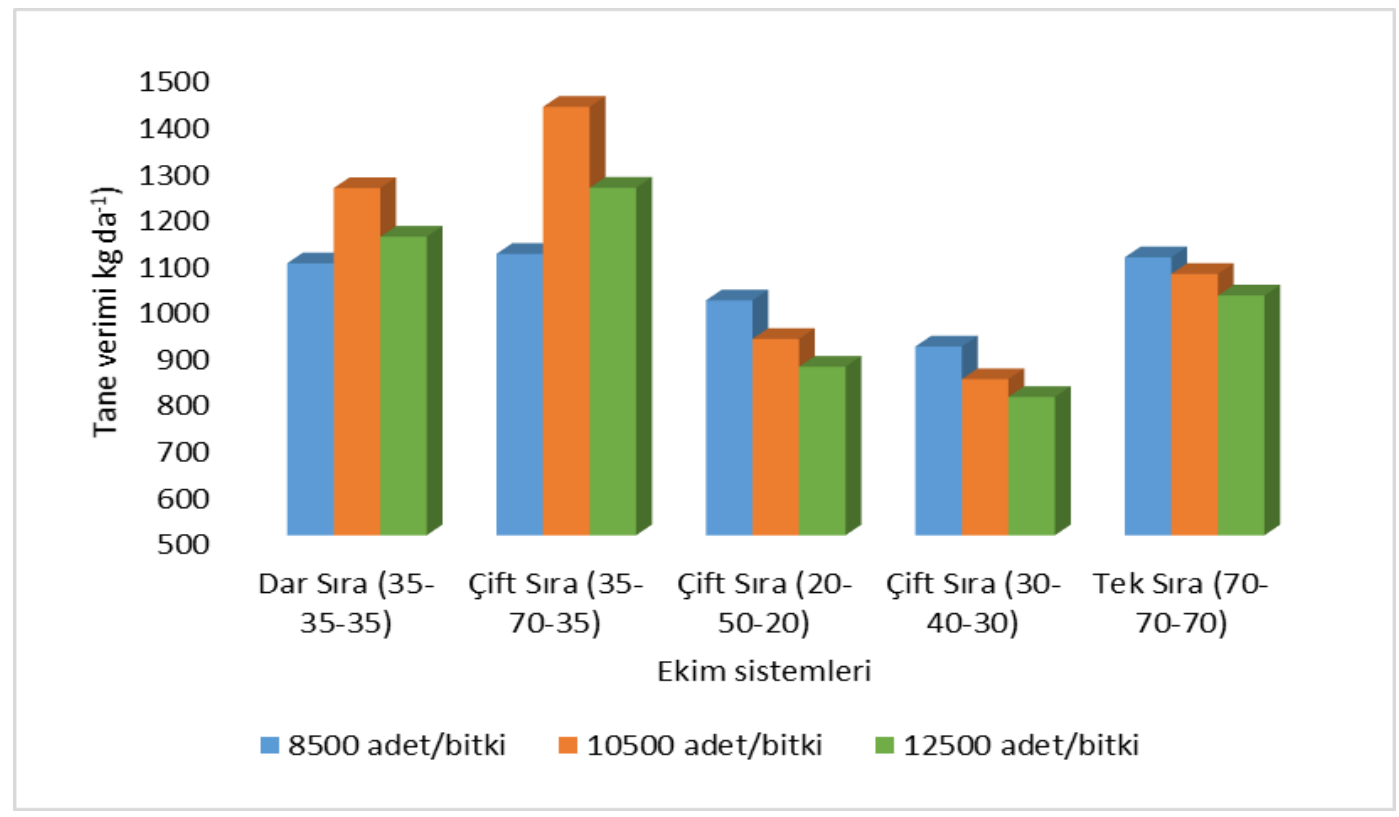

Şekil 2. Farklı ekim sistemleri ve değişik bitki yoğunluklarının mısır bitkisinin tane verimine etkisi

\section{Sonuç ve Öneriler}

Araştırma sonuçlarına göre; ekim sistemleri ve bitki yoğunluğu bakımından incelenen özelliklerde istatistiki olarak farklılık gözlenmiştir. Çift sira (35-70-35) ekim sisteminden $1261.55 \mathrm{~kg} \mathrm{da}^{-1}$ ile diğerlerinden daha yüksek tane verimi elde edilmiştir. Çift sıra $(35-70-35 \mathrm{~cm})$ ekim sisteminden geleneksel ekim sistemi olan tek sira $(70-70-70 \mathrm{~cm})$ ekim sistemine oranla daha yüksek tane verimi elde edilmiştir. Bitki yoğunluğu bakımından en yüksek tane verimi ise $1100.40 \mathrm{~kg} \mathrm{da}^{-1}$ ile 10500 bitki $\mathrm{da}^{-1}$ bitki sayısından elde edilmiştir. Dekarda bitki sayısının artması ile bitki boyu ve bitkide yaprak sayısı artarken, kaçan kalınlığı, koçan uzunluğu, koçanda tane sayısı, koçanda tane ağırlığı ve bin tane ağırlığı azalmıştır. Ekim sistemi $\mathrm{x}$ bitki yoğunluğu interaksiyonunda ise en yüksek tane verimi ise $1425.66 \mathrm{~kg} \mathrm{da}^{-1}$ ile çift sira (35-70-35) x 10500 bitki $\mathrm{da}^{-1}$ ekim sisteminden elde edilmiştir. Çift sıra (35-70-35) x 10500 bitki da $^{-1}$ interaksiyonu denenen ekim sistemleri arasında en iyi kombinasyon olarak belirlenmiştir.

\section{Kaynaklar}

Anonim (2012) Şanlıurfa meteoroloji müdürlüğü iklim verileri. Şanlıurfa.

Anonim (2015a) URL: http://www.twinrow.com/. (Erişim tarihi: 15.05.2021). 


\section{Farklı Çift Sıra, Dar Sıra ve Tek Sıra Ekim Sistemlerinde Değişik Bitki Yoğunluklarının Mısır Bitkisinin (Zea mays L. indentata) Verim ve Verim Öğelerine Etkisi}

Anonim (2015b) URL:

http://www.agrigold.com/. (Erişim tarihi: 15.05.2021).

Abuzar, M.R., Sadozai, G.U., Baloch, M.S., Baloch, A.A., Shah, I.H., Javaid, T., Hussain, N. (2011) Effect of plant population densities on yield of maize. $J$. Anim. Plant Sci. 21:692-695.

Alıcı, S. (2005) Kahramanmaraş koşullarında farklı azot dozları ile sıra üzeri ekim mesafelerinin II. ürün misir bitkisinde verim, verim unsurları ve bazı tarımsal karakterlere etkisi üzerine bir araştırma. Çukurova Üniv. Fen Bil. Enst. Adana, 137 s.

Amaral Filho, J.P.R., Filho, D.F. Farinelli R., Barbosa J.C. (2005) Row spacing, population density and nitrogen fertilization in maize. R. Bras. Ci. Solo 29:467-473.

Andrade F.H., Calvino P., Cirilo A., Barbieri P. (2002) Yield responses to narrow rows depend on increased radiation interception, Agronomy Journal 94(5):975-980.

Bruns H.A., Ebelhar M., Wayne, K., Abbas H. (2012) Comparing single-row and twinrow corn production in the Middle South. Online. Crop Management Doi:10.1094/Cm-2012-0404-01-Rs.

Bukhsh, M.A.H.A., Ahmad, R., Cheema, Z.A., Ghafoor A. (2008) Production potential of three maize hybrids as influenced by varying plant density. Pak. J. Agri. Sci. 45(4): 413-417.

Cox, W.J., Hanchar J.J., Knoblauch, W.A., Cherney J.H. (2006) Growth, yield, quality, and economics of corn silage under different row spacing. Agronomy Journal 98(1):163-167.

Çarpıcı, E. B. (2009). Bitki yoğunluğu ve farklı miktarda azot uygulamalarının stres fizyolojisi açısından silajlı mısır yetiştiriciliğinde değerlendirilmesi. Doktora tezi, Uludağ Üniversitesi Fen Bilimleri Enstitüsü, Bursa.

Çokkızgın, A. (2002) Kahramanmaraş koşullarında farklı azot dozları ile sıra üzeri ekim mesafelerinin II. ürün misır bitkisinde verim, verim unsurları ve fizyolojik özelliklere etkisi. Sütçü İmam Üniv. Fen Bil. Enst. K.Maraş, 72 s.

Dinç, U., Şenol, S., Sayın, M., Kapur, S., Güzel, N. (1988) Güneydoğu Anadolu Bölgesi Toprakları (GAT) I. Harran Ovası, TÜBİTAK, Tarım Ormancılık Araştırma Grubu, Güdümlü Araştırma Projesi Kesin Sonuç Raporu, TAOG, 534, Adana.

Emeklier, H.Y., Kün, E. (1988) İç Anadolu'da sulu koşullarda ikinci ürün tane mısır ve silaj mısır yetiştirme olanakları ve yem değerlerinin saptanması. Doğa Tarım ve Orman Dergisi, 12(2):178-179.

Eskandarnejad, S., Khorasani, S.K., Bakhtiari, S., Heidarian, A.R. (2013) Effect of row spacing and plant density on yield and yield components of sweet corn (Zea mays L. Saccharata) varieties. Advanced Crop Science 3(1):81-88.

Gözübenli H., Kılınç, M., Şener O., Konuşkan, Ö. (2004) Effects of single ve twin row planting on yield and yield components in maize. Asian Journal of Plant Sciences 3(2):203-206.

Gözübenli H. (2010) Influence of planting patterns and plant density on the performance of maize hybrids in the eastern mediterranean conditions. International Journal of Agriculture \& Biology 12(4):556-560.

Gregg, A., Johnson, Hoverstad T. R., Greenwald R. E. (1998) Integrated weed management using narrow corn spacing, herbicides, ve cultivation. Agronomy Journal, 90(1):4046.

Karlen, D.L., Camp C.R. (1985) Row spacing, plant population, ve water management effects on corn in the atlantic coastal plain. Agronomy Journal 77(3):393-398.

Karlen, D.L., M.J. Kasperbauer, Zublena, J.P. (1987) Row spacing effects on corn in the Southeastern U.S. Appl. Agric. Res. 2(2):65-73.

Liu, W., Tollenaar, M., Stewart, G., Deen, W. (2004). Within-row plant spacing variability does not affect corn yield. Agron. J. 96:275-280.

Mahbubul, M., Alam, M.D., Basher, M., Karim, A., Rahman, M.A., Rafiqul Islam, M. (2003) Effect of rate of nitrogen fertilizer 


\section{Farklı Çift Sıra, Dar Sıra ve Tek Sıra Ekim Sistemlerinde Değişik Bitki Yoğunluklarının Mısır Bitkisinin (Zea mays L. indentata) Verim ve Verim Öğelerine Etkisi}

and population density on the yield and yield attributes of maize. Pakistan Journal of Biological Sciences 6 (20):1770-1773.

Mcgrath, C., Butler, J, Havlovic, B. (2013). Twin Row Corn Study, Iowa State University, Armstrong Research and Demonstration Farm. Http://www.Ag. İastate.Edu/Farms/04reports/Arm/Twinro wcornstudy.Pdf (Erişim : 18.05.2021).

Otegui, M., Andrade, F.H. (2000) New relationships between light interception, ear growth, and kernel set in maize. In: Westgate, M.E., Boote, K.J. (Eds.), Physiology ve Modeling Kernel Set in Maize. CSSA, Madison, WI, pp. 89-102.

Pagano, E., Maddoni, G.A. (2007) Intra-specific competition in maize: Early establishment hierarchies differ in plant growth and biomass partitioning to the ear around silking. Field Crops Res. 101:306-320.

Robles, M., Ciampitti, I., Vyn, TJ. (2012) Responses of maize hybrids to twin-row spatial arrangement at multiple plant densities. Agron. J. 104:1747-1756. http:dx.doi.org/10.2134/agronj2012.0231

Saberali, S.F. (2007) Influence of plant density and planting pattern of corn on its growth and yield under competition with common lambesquarters (Chenopodium album L.). Pajouhesh and Sazandegi 74: 143-152.

Saruhan, V., Şireli, D. (2005) Misir (Zea mays L.) bitkisinde farklı azot dozları ve bitki sıklığının koçan, sap ve yaprak verimlerine etkisi üzerine bir araştırma. Harran Ü.Z.F.Dergisi 9 (2):45-53.

Sangoi, L., Gracietti, M.A., Rampazzo, C., Bianchetti, P. (2002). Corn plant varieties and plant population genetics. Field Crops Research 79(1): 39.

Sharar, M.S., Ayub, M., Nadeem, M.A., Ahmad, N. (2002). Effect of different rates of nitrogen and phosphorus on growth and grain yield of maize (Zea mays L.). Asian Journal of Plant Sciences 2(3): 347-349.

Shakarami, G.H., M. Rafiee (2009) Response of corn to planting pattern and density in Iran. American-Eurasian J. Agric. Environ Sci. 5(1) : 69-73.
Stahl, L., Coulter, J.A., Bau, D. (2009) Narrowrow corn production in Minnesota. Online. Univ. of MN, M1266-2009.

Şirikçi. M. (2006) Kahramanmaraş koşullarında üç mısır çeşidinde farklı bitki sıklığının verim ve bazı özelliklere etkisi. Çukurova Üniv. Fen Bil. Enst. Doktora Tezi, Adana.

Turgut, İ. (2000) Bursa koşullarında yetiştirilen şeker mısırında bitki sıklığının ve azot dozlarının taze koçan verimi ile verim öğeleri üzerine etkisi. Turk J Agric For. 24: 341-347.

Yılmaz, Y., Konuşkan, Ö., Gül, İ., Ülger, A.C. (2005) Diyarbakır'da ikinci ürün koşullarında yetişme süreleri farklı at dişi melez misır çeşitlerinde iki ekim zamanının, tane verimi ve bazı tarımsal özelliklere etkisinin saptanması. GAP IV. Tarım Kongresi 21-23 Eylül 2005 (1.Cilt) Şanlıurfa, sayfa:867-873.

Yılmaz, S., Erayman M., Gözübenli H., Can E. (2008) Twin or narrow row planting patterns versus conventional planting in forage maize production in the Eastern Mediternean. Cereal Research Communications 36(1): 189-199.

Yurtsever, N. (1984) Deneysel İstatistik Metotları. Toprak ve Gübre Araştırma Enstitüsü Genel Yayın No:121, Ankara.

Widdicombe, D., Thelen, K.D. (2002) Row width and plant density effect on corn forage hybrids. Agron. J. 94:326-330.

Zeidan, M.S., Amany, A., Bahr El-Kramany, M.F. (2006) Effect of $\mathrm{N}$ fertilizer and plant density on yield and quality of maize in sandy soil. Research Journal of Agriculture and Biological Sciences 2(4):156-161. 
Farklı Çift Sıra, Dar Sıra ve Tek Sıra Ekim Sistemlerinde Değişik Bitki Yoğunluklarının Mısır Bitkisinin (Zea mays L. indentata) Verim ve Verim Öğelerine Etkisi 